\title{
Molecular evolution of the growth hormone-releasing hormone/pituitary adenylate cyclase-activating polypeptide gene family. Functional implication in the regulation of growth hormone secretion
}

\section{Montero, L Yon, S Kikuyama ${ }^{1}$, S Dufour ${ }^{2}$ and $\mathbf{H}$ Vaudry}

European Institute for Peptide Research (IFRMP 23), Laboratory of Cellular and Molecular Neuroendocrinology, INSERM U413, UA CNRS, University of Rouen, 76821 Mont-Saint-Aignan, France

${ }^{1}$ Laboratory of Endocrinology, Department of Biology, School of Education, Waseda University, Nishi-Waseda 1-6-1, Tokyo 169-8050, Japan

${ }^{2}$ Laboratory of General and Comparative Physiology, CNRS UMR 8572, National Museum of Natural History, 75005 Paris, France

(Requests for offprints should be addressed to H Vaudry)

\begin{abstract}
Growth hormone-releasing hormone (GHRH) and pituitary adenylate cyclase-activating polypeptide (PACAP) belong to the same superfamily of regulatory neuropeptides and have both been characterized on the basis of their hypophysiotropic activities. This review describes the molecular evolution of the GHRH/PACAP gene family from urochordates to mammals and presents the hypothesis that the respective roles of GHRH and PACAP in the control of GH secretion are totally inverted in phylogenetically distant groups of vertebrates. In mammals, GHRH and PACAP originate from distinct precursors whereas, in all submammalian taxa investigated so far, including birds, amphibians and fish, a single precursor encompasses a GHRHlike peptide and PACAP. In mammals, GHRHcontaining neurons are confined to the infundibular
\end{abstract}

and dorsomedial nuclei of the hypothalamus while PACAP-producing neurons are widely distributed in hypothalamic and extrahypothalamic areas. In fish, both GHRH- and PACAP-immunoreactive neurons are restricted to the diencephalon and directly innervate the adenohypophysis. In mammals and birds, GHRH plays a predominant role in the control of GH secretion. In amphibians, both GHRH and PACAP are potent stimulators of GH release. In fish, PACAP strongly activates GH release whereas GHRH has little or no effect on GH secretion. The GHRH/PACAP family of peptides thus provides a unique model in which to investigate the structural and functional facets of evolution.

Fournal of Molecular Endocrinology (2000) 25, 157-168

\section{INTRODUCTION}

Growth hormone-releasing hormone (GHRH) was initially characterized from a human pancreatic tumor on the basis of its ability to stimulate growth hormone $(\mathrm{GH})$ secretion from adenohypophyseal cells (Guillemin et al. 1982, Rivier et al. 1982).
Pituitary adenylate cyclase-activating polypeptide (PACAP) was first identified from the ovine hypothalamus as a result of its capability of stimulating cAMP formation in rat anterior pituitary cells (Miyata et al. 1989). Soon after the discovery of PACAP, it became apparent that these two hypophysiotropic neuropeptides exhibit a 


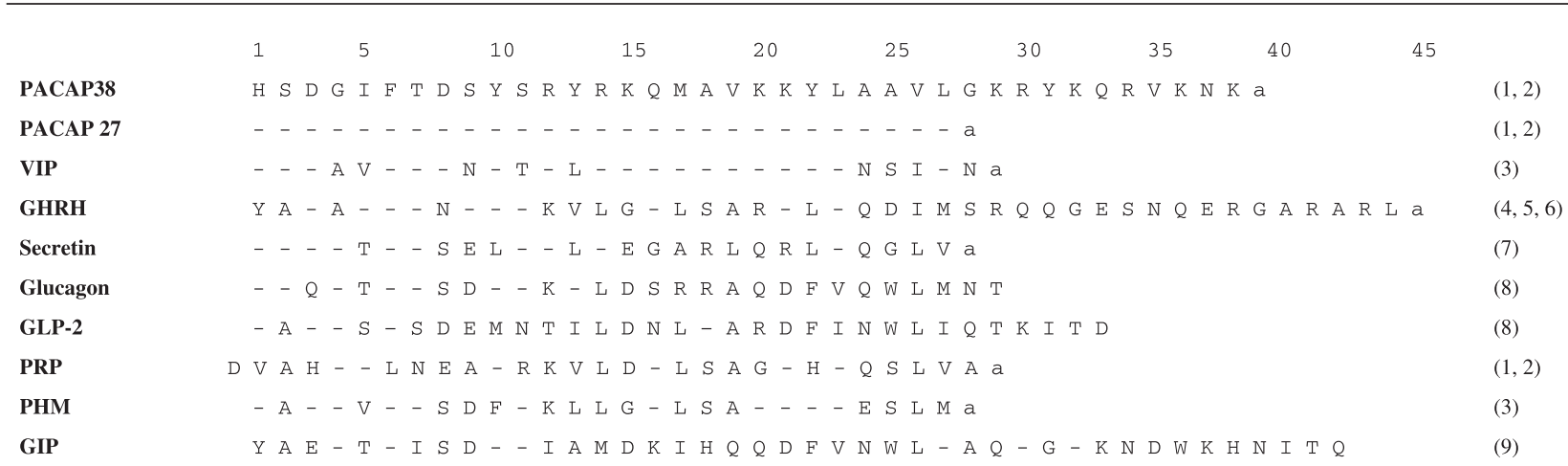

FIGURE 1. Primary structures of the different members of the GHRH superfamily in human. (1) Kimura et al. 1990, (2) Ohkubo et al. 1992, (3) Itoh et al. 1983, (4) Rivier et al. 1982, (5) Guillemin et al. 1982, (6) Ling et al. 1984, (7) Carlquist et al. 1985, (8) Bell et al. 1983, (9) Moody et al. 1984. Abbreviations as in the text; a, amidated; -, amino acid identical to that of PACAP38.

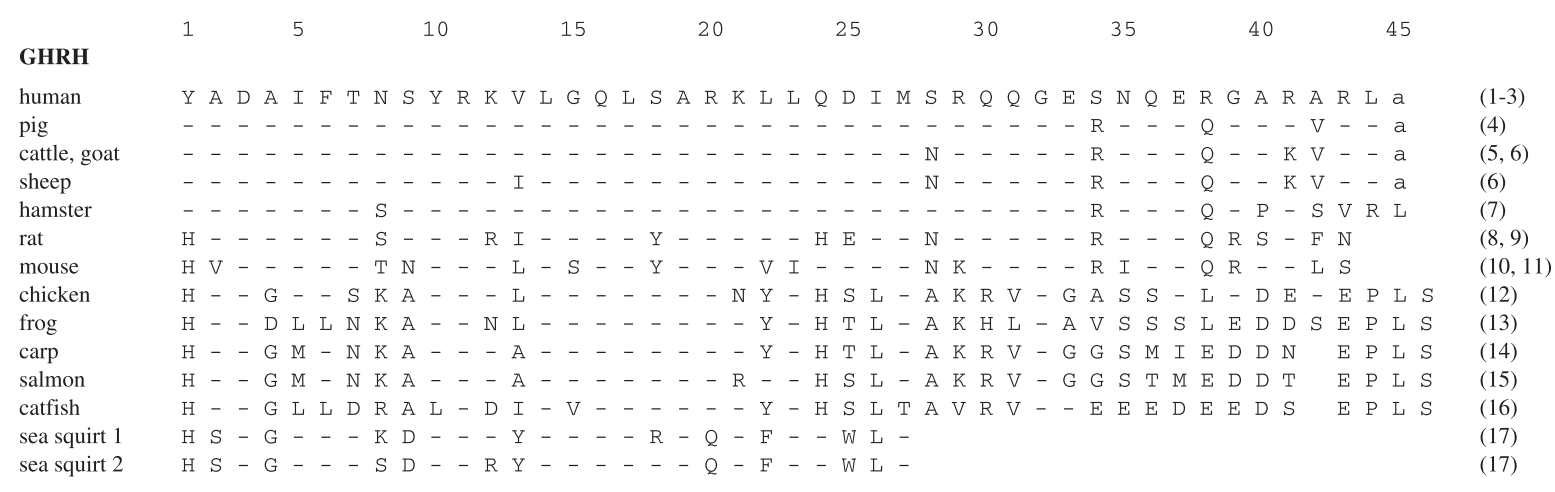

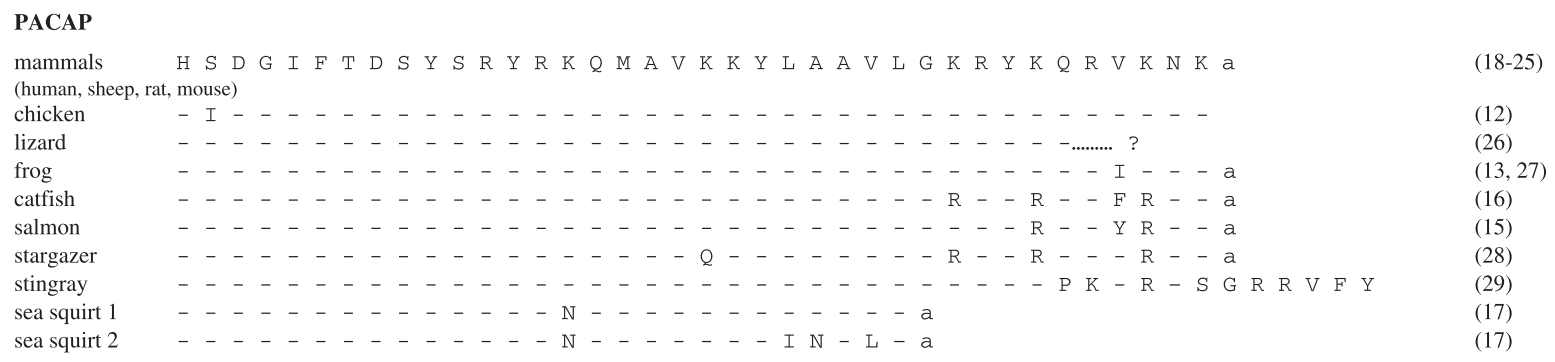

FIGURE 2. Comparison of the primary structures of GHRH and PACAP in different species of vertebrates and urochordates. (1) Rivier et al. 1982, (2) Guillemin et al. 1982, (3) Ling et al. 1984, (4) Böhlen et al. 1983, (5) Esch et al. 1983, (6) Brazeau et al. 1984, (7) Ono et al. 1994, (8) Spiess et al. 1983, (9) Böhlen et al. 1984, (10) Frohman et al. 1989, (11) Suhr et al. 1989, (12) McRory et al. 1997, (13) Alexandre et al. 2000, (14) Vaughan et al. 1992, (15) Parker et al. 1993, (16) McRory et al. 1995, (17) McRory \& Sherwood 1997, (18) Miyata et al. 1989, (19) Kimura et al. 1990, (20) Miyata et al. 1990, (21) Ogi et al. 1990, (22) Hosoya et al. 1992, (23) Ohkubo et al. 1992, (24) Okazaki et al. 1995, (25) Yamamoto et al. 1998, (26) Pohl \& Wank 1998, (27) Chartrel et al. 1991, (28) Matsuda et al. 1997a, (29) Matsuda et al. 1998. a, amidated; -, amino acid identical to that of human GHRH or mammalian PACAP.

number of structural and functional similarities. (i) They stand among the largest hypothalamic neurohormones discovered so far. (ii) They possess considerable sequence similarity so that it is generally accepted that they arose by genomic duplication of the exon encoding a common ancestor. (iii) They both appeared very early during evolution prior to the emergence of vertebrates. (iv) They are widely distributed in peripheral organs, notably in the gut, pancreas, ovary and testis. (v) Their biological effects are mediated through 7-transmembrane domain receptors positively coupled to adenylyl cyclase. Besides these similarities, GHRH and PACAP display one major 


\section{Mammals}
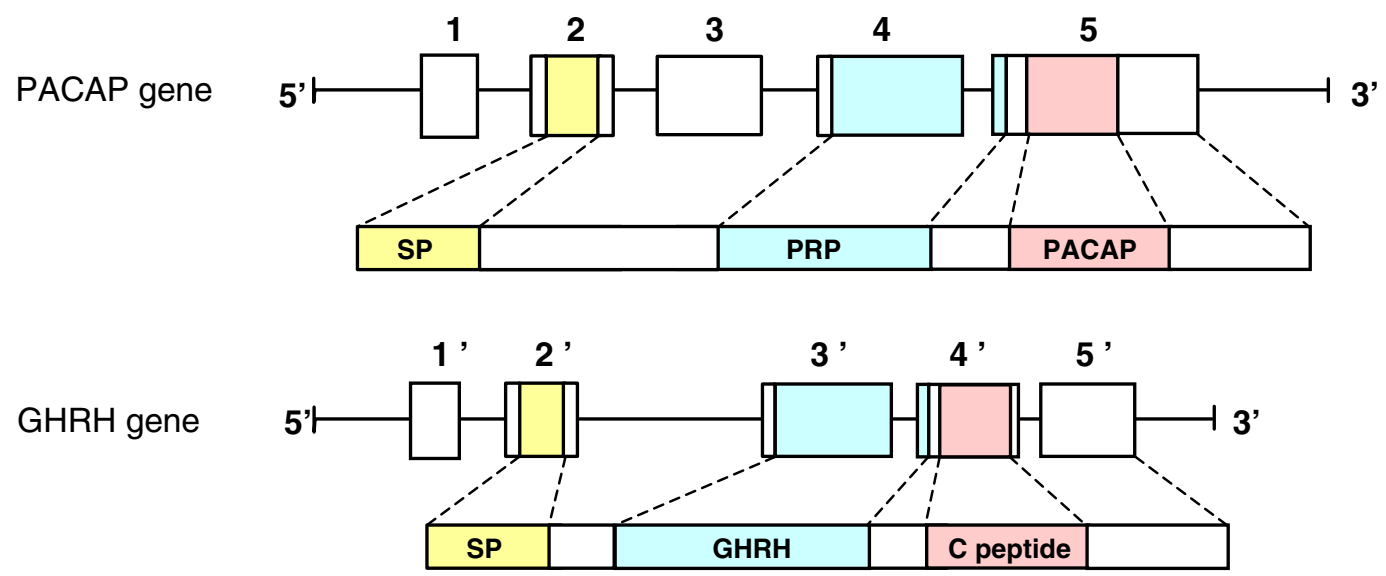

\section{Infra-mammalian Vertebrates}

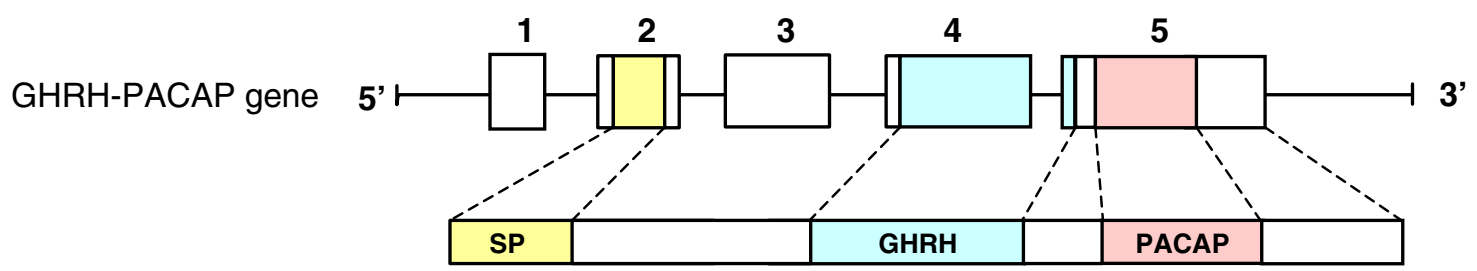

\section{Urochordate Invertebrates}
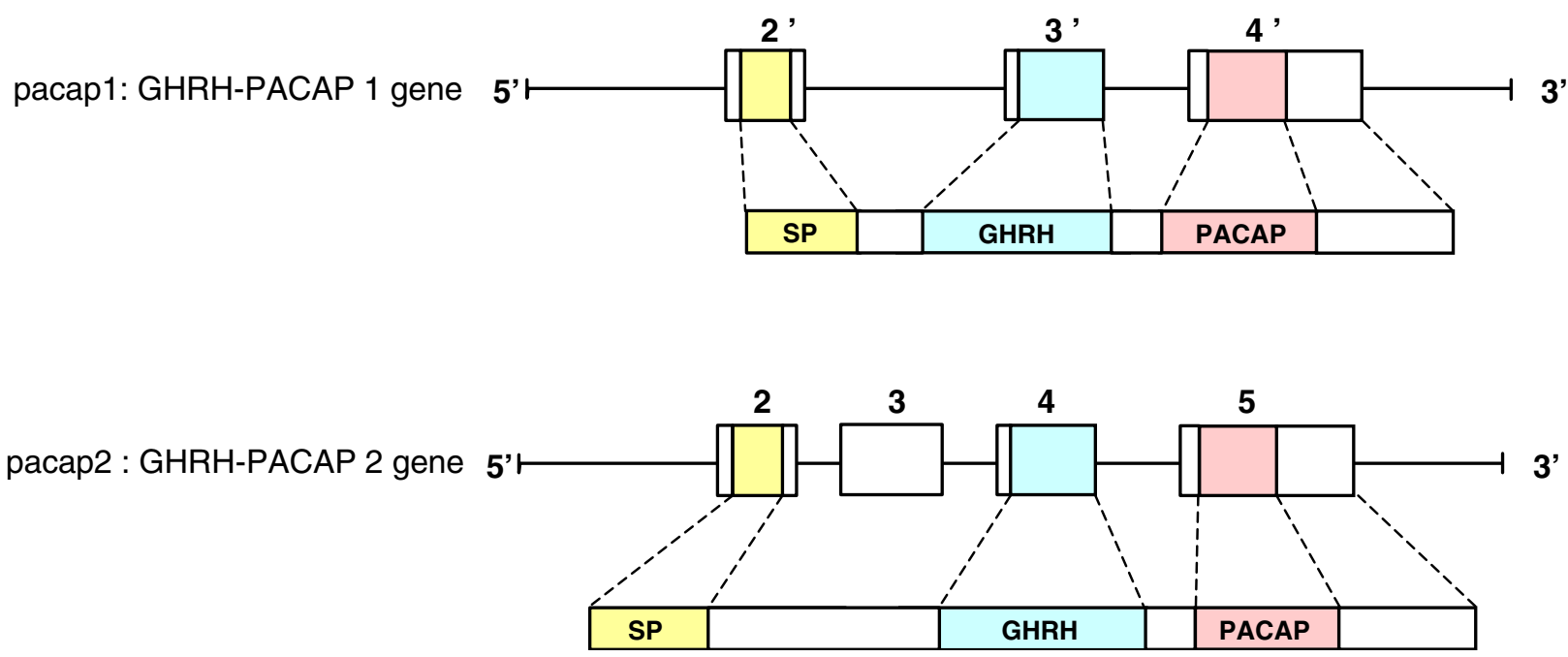

FIGURE 3. Organization of the GHRH, PACAP and GHRH/PACAP genes of vertebrates and invertebrates. Exon numbering follows that used for the mammalian genes. 
difference: the sequence of GHRH has been poorly conserved, even in closely related species, while the sequence of PACAP has been extremely well preserved during evolution.

Examination of the amino acid sequences of GHRH and PACAP clearly indicates that these two neuropeptides belong to a superfamily of regulatory peptides which encompasses glucagon, secretin, vasoactive intestinal polypeptide (VIP), peptide histidine methionine (PHM) or peptide histidine isoleucine (PHI), gastric inhibitory peptide (GIP), and glucagon-like peptides (GLPs) (Fig. 1) (Campbell \& Scanes 1992, Kieffer \& Habener 1999). Molecular characterization of the GHRH and PACAP precursors in several representative species of urochordates and vertebrates, together with studies on their physiological implication in the control of pituitary hormone secretion, have provided important information pertaining to the evolutionary aspects of their structures and functions. The aim of the present review is to summarize the current knowledge regarding the phylogenetic origin and the evolution of the respective roles of GHRH and PACAP in the regulation of $\mathrm{GH}$ secretion.

\section{MOLECULAR DIVERSITY OF GHRH AND PACAP}

\section{Evolution of the primary structures of GHRH and PACAP}

The sequence of GHRH was initially determined from a tumor which had caused acromegaly (Guillemin et al. 1982, Rivier et al. 1982). Subsequently, the primary structure of the peptide has been elucidated in a number of species, either directly determined after peptide purification or deduced from a cloned cDNA. In contrast to most hypophysiotropic neurohormones whose sequences have been generally well conserved during evolution, the primary structure of GHRH is highly variable (Fig. 2). In particular, rat and mouse GHRHs only exhibit $67 \%$ sequence identity, which is by far the lowest degree of similarity for regulatory neuropeptides observed between these two rodent species.

Two molecular forms of PACAP with 38 (PACAP38) and 27 (PACAP27) amino acids were originally isolated from the sheep hypothalamus (Miyata et al. 1989, 1990). The sequence of PACAP has been remarkably well preserved from the sea squirt (an urochordate invertebrate) to the human (Fig. 2). In particular, the sequence of PACAP38 is identical in all mammalian species studied so far. In other vertebrates, strong evolutionary pressure has acted to preserve the sequence of the $\mathrm{N}$-terminal domain which corresponds to the biologically active region of the molecule (Gonzalez et al. 1998). It is noteworthy that the sequences of the two tunicate PACAP27 variants exhibit only one and four amino acid substitutions as compared with their mammalian ortholog (Miyata et al. 1990, McRory \& Sherwood 1997). Such a high degree of peptide sequence conservation between two taxa which have diverged from a common ancestor some 600 million years ago (McRory \& Sherwood 1997) indicates that PACAP fulfils important biological functions.

\section{Evolution of the structure of the GHRH and PACAP precursors}

In mammals, the GHRH and PACAP precursors are encoded by two distinct genes (Mayo et al. 1985a, Hosoya et al. 1992). Each of these precursors encompasses two related peptides: the GHRH precursor comprises GHRH and a C-terminal flanking peptide called C-peptide, while the PACAP precursor comprises PACAP and an N-terminal flanking peptide called PACAP-related peptide or PRP (Fig. 3). Comparison of the sequences of these peptides reveals a higher degree of similarity between PRP and GHRH than between PRP and PACAP (45\% and 21\% respectively in human).

In contrast, in all submammalian species investigated so far, a GHRH-like peptide and PACAP are located on the same precursor (Fig. 3). To date, the cDNA encoding the GHRH/PACAP precursor has been characterized in the chicken Gallus domesticus (McRory et al. 1997), the frog Rana ridibunda (Alexandre et al. 2000), the catfish Clarius macrocephalus (McRory et al. 1995) and the salmon Oncorhynchus nerka (Parker et al. 1993). In birds, amphibians and fish, alternative splicing of the primary transcript can generate either a long mRNA encompassing both the GHRH and PACAP sequences, or a short mRNA lacking the GHRH sequence (McRory et al. 1997, Parker et al. 1997, Alexandre et al. 2000). Two cDNAs encoding GHRH/PACAP precursors have also been cloned in an urochordate, the sea squirt Chelyosoma productum (McRory \& Sherwood 1997). The organization of the GHRH/PACAP genes in urochordates exhibits strong similarities with those of vertebrates (Fig. 3). Sequence analysis of the two GHRH/PACAP precursors of the sea squirt reveals a higher degree of similarity between the two GHRH sequences $(89 \%)$ and the two PACAP sequences $(89 \%)$ than between the GHRH and PACAP sequences within each precursor $(41 \%$ for the GHRH/PACAP1 precursor and $48 \%$ for the 


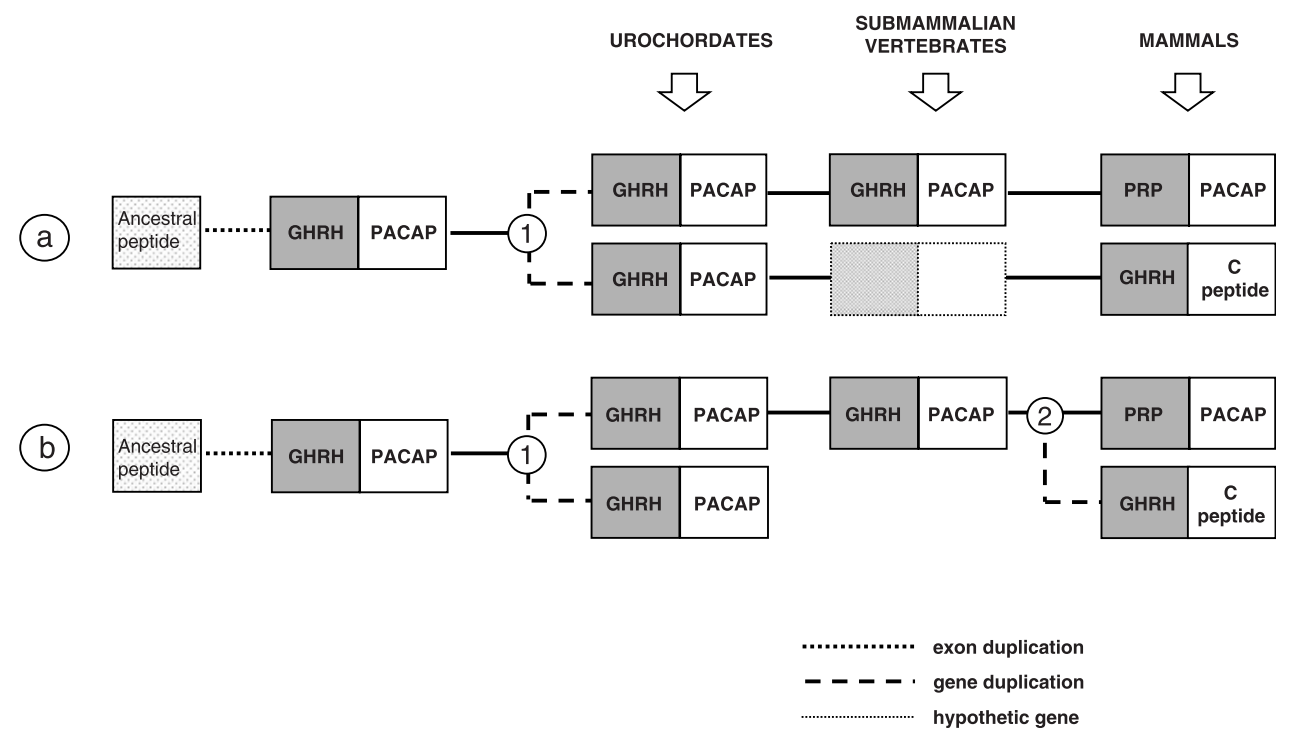

FIGURE 4. Proposed evolutionary history of the GHRH/PACAP precursor family. In both hypotheses a and b, it is assumed that exon duplication, leading to the appearance of the GHRH/C peptide and PRP/PACAP sequences, occurred before gene duplication. Hypothesis a: a single duplication would have occurred before the emergence of urochordates. Hypothesis b: two duplications would have occurred independently in the urochordates and in a common ancestor of mammals.

GHRH/PACAP2 precursor), suggesting that exon duplication generating GHRH and PACAP occurred before duplication of the ancestral gene (Fig. 4).

Since only one GHRH/PACAP cDNA has been characterized to date in teleosts (Parker et al. 1993, McRory et al. 1995), amphibians (Alexandre et al. 2000) and birds (McRory et al. 1997) while two distinct cDNAs encoding either GHRH or PACAP have been cloned in rat (Mayo et al. 1985b, Ogi et al. 1990), mouse (Frohman et al. 1989, Suhr et al. 1989, Okazaki et al. 1995) and human (Gübler et al. 1983, Mayo et al. 1983, 1985a, Kimura et al. 1990, Hosoya et al. 1992, Ohkubo et al. 1992), it has been proposed that a gene duplication event occurred just before the emergence of mammals (Arimura 1998, Hoyle 1998, Vaudry et al. 2000). However, several observations suggest that a second gene encoding a GHRH-like peptide may well exist in nonmammalian species (Fig. 4). In particular, two GHRH/PACAP genes are present in urochordates, suggesting that duplication of the ancestral gene may have occurred very early during evolution (McRory \& Sherwood 1997). In fact, the organization of the GHRH/PACAP1 gene of the sea squirt exhibits much similarity with that of the mammalian GHRH precursor gene, while the structure of the GHRH/PACAP2 gene of the sea squirt resembles that of the mammalian PACAP precursor gene (Fig. 4), suggesting that the two urochordate genes may be orthologous to the two mammalian genes. In that case, the existence of two GHRH/PACAP precursors should also occur in submammalian vertebrate species. Indeed, Southern blot analysis of salmon genomic DNA has revealed the existence of at least two bands hybridizing with a probe including the GHRH/ PACAP coding region (Parker et al. 1993) and two variants of GHRH/PACAP cDNAs have recently been cloned in the goldfish (Leung et al. 1999), confirming the existence of more than one GHRH/ PACAP gene in teleosts.

\section{EVOLUTION OF THE DISTRIBUTION OF GHRH AND PACAP NEURONS IN THE BRAIN}

In mammals, GHRH-containing neurons are strictly located in the arcuate and the dorsomedial nuclei of the hypothalamus (Mayo et al. 1995), whereas PACAP-containing perikarya are widely distributed, not only in the hypothalamus, but also in the thalamus, septum, cortex, amygdala, hippocampal area, cerebellum and pons (Arimura et al. 1991, Koves et al. 1991, 1994, Ghatei et al. 1993, Legradi et al. 1994, Nielsen et al. 1998) (Fig. 5a).

Fournal of Molecular Endocrinology (2000) 25, 157-168 Downloaded from Bioscientifica.com at 04/26/2023 02:59:22AM via free access 

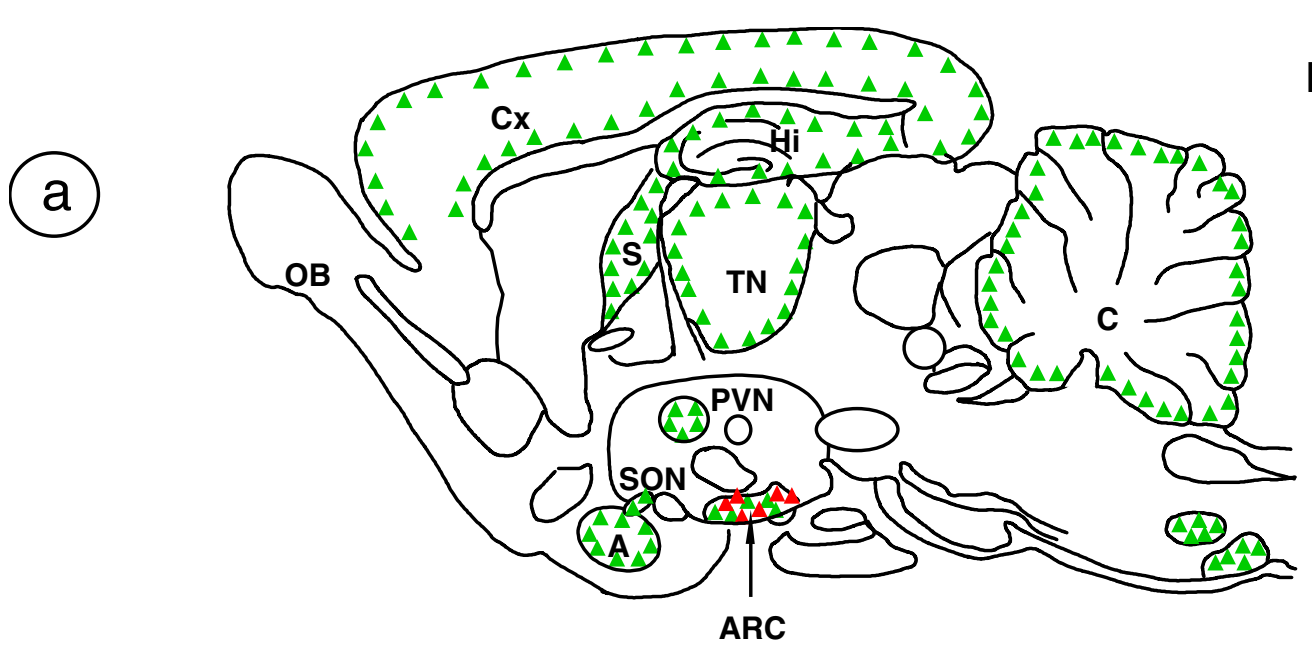

Rat

(b)

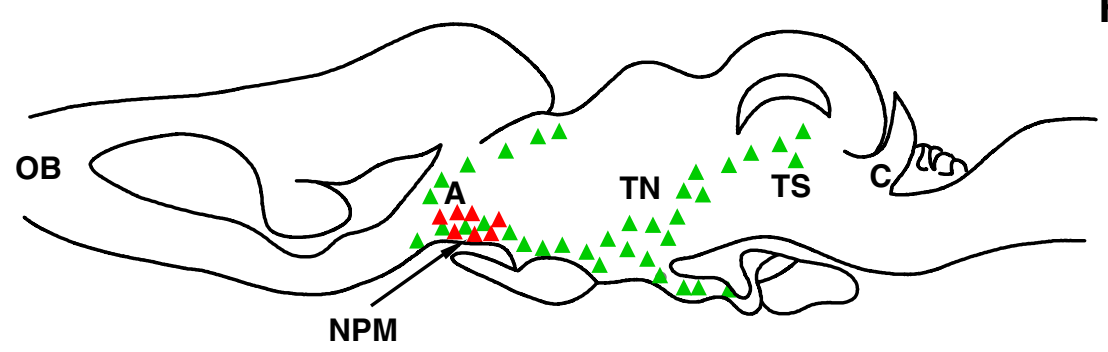

Frog
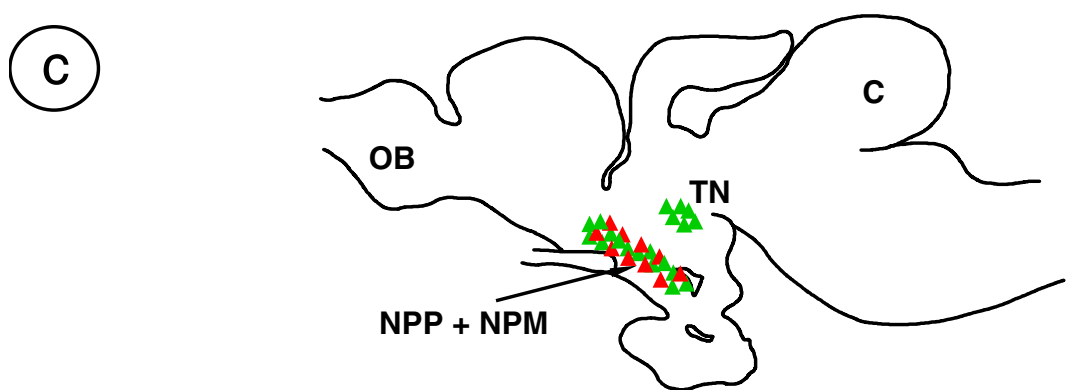

Eel

FIGURE 5. Schematic parasagittal sections through (a) rat, (b) frog and (c) eel brain depicting the distribution of GHRH and PACAP perikarya. Red triangles, GHRH-immunoreactive cell bodies; green triangles, PACAPimmunoreactive cell bodies. A, amygdala; ARC, arcuate nucleus; C, cerebellum; Cx, cortex; Hi, hippocampus; NPM, magnocellular preoptic nucleus; NPP, posterior preoptic nucleus; OB, olfactory bulb; PVN, paraventricular nucleus; $\mathrm{S}$, septum; SON, supraoptic nucleus; TN, thalamic nucleus; TS, torus semicircularis. Adapted from Gonzalez et al. 1998, Montero et al. 1998 and Yon et al. 1992.

In birds, the distribution of GHRH neurons has never been reported while the location of PACAP-containing neurons has been studied in the chicken forebrain (Peeters et al. 1998a). PACAP- immunoreactive cell bodies are particularly abundant in the ventral aspect of the supraoptic nucleus, as well as in the magnocellular subdivisions of the preoptic and paraventricular nuclei (Peeters et al. 1998a). 
In amphibians, unfortunately, the distribution of GHRH neurons has been exclusively investigated in the hypothalamo-hypophyseal system, so that the presence of GHRH-immunoreactive cell bodies has only been described in the magnocellular part of the preoptic nucleus (Marivoet et al. 1988). The existence of PACAP-positive perikarya has been reported in the frog hypothalamus as well as in extrahypothalamic areas including the thalamus, amygdala and torus semicircularis (Yon et al. 1992) (Fig. 5b). Since, in frog, a GHRH-like peptide and PACAP are encoded by the same gene (Alexandre et al. 2000), it is conceivable that GHRH-like immunoreactivity could have a more widespread distribution than initially described (Marivoet et al. 1988). Thus, the location of GHRH-containing neurons in the amphibian brain outside the hypothalamic region deserves to be investigated.

In fish, GHRH-immunoreactive neurons are primarily located in the magnocellular and parvocellular portions of the preoptic nucleus; a few GHRH-positive neurons are also found in the rostral part of the nucleus lateralis tuberis (Marivoet et al. 1988, Olivereau et al. 1990). Similarly, PACAP-positive cell bodies are found in the preoptic nucleus and in the nucleus lateralis tuberis (Matsuda et al. 1997b, Montero et al. 1998, Yoshida et al. 1999) (Fig. 5c). The expression of PACAP mRNA in the preoptic area has recently been confirmed by in situ hybridization (Satoh et al. 1999). The co-localization of GHRH and PACAP in the same regions of the fish diencephalon is consistent with the occurrence of a GHRH-like peptide and PACAP within the same precursor (Parker et al. 1993, McRory et al. 1995). Interestingly, in teleost fish, fibers immunoreactive for GHRH and PACAP directly innervate the pars distalis (Marivoet et al. 1988, Olivereau et al. 1990, Matsuda et al. 1997b, Montero et al. 1998), suggesting that both GHRH and PACAP may be involved in the control of pituitary hormone secretion.

\section{EVOLUTION OF THE REGULATION OF GH SECRETION BY GHRH AND PACAP}

In mammals, $\mathrm{GH}$ secretion is primarily under the stimulatory control of GHRH and the inhibitory influence of somatostatin (Bertherat et al. 1995). Studies aimed at investigating the effect of PACAP on GH secretion have led to controversial results. Specifically, some data suggest that PACAP stimulates GH release in rat (Goth et al. 1992, Hart et al. 1992, Jarry et al. 1992, Leonhardt et al. 1992,
TABLE 1. Relative implication of GHRH and PACAP in the control of GH secretion in vertebrates

\begin{tabular}{lll} 
& GHRH & PACAP \\
\cline { 2 - 2 } Taxa & & \\
Mammals & +++ & \\
Birds & +++ & + \\
Reptiles & $?$ & $?$ \\
Amphibians & +++ & +++ \\
Teleosts & $+/ 0$ & +++ \\
& & \\
\hline
\end{tabular}

Nagy et al. 1993, Wei et al. 1993, Velkeniers et al. 1994), sheep (Sawangjaroen et al. 1997) and cattle (Hashizume et al. 1994), whereas other reports indicate that PACAP has no effect on GH secretion (Miyata et al. 1989, Culler \& Paschall 1991, Jarry et al. 1992, Sawangjaroen \& Curlewis 1994). In humans, intravenous administration of PACAP does not modify plasma GH levels (Chiodera et al. 1996) and PACAP is less potent than GHRH in stimulating $\mathrm{GH}$ release from somatotropic adenoma cells in primary culture (Adams et al. 1994). In birds, PACAP has been found to induce a dose-dependent stimulation of cAMP formation by chicken pituitary cells. However, PACAP causes only a modest increase of $\mathrm{GH}$ release as compared with the robust stimulatory effect of human GHRH (Peeters et al. 1998b). Taken together, these data indicate that PACAP probably plays a minor role in the control of $\mathrm{GH}$ secretion in mammals and birds (Table 1).

In amphibians, frog (f) PACAP stimulates $\mathrm{GH}$ secretion in the European green frog Rana ridibunda (Martinez-Fuentes et al. 1994) and the bullfrog Rana catesbeiana (S Kikuyama, unpublished data). Frog PACAP stimulates adenylyl cyclase activity in frog pituitary slices (Yon et al. 1993) and increases cytosolic calcium concentration in cultured frog somatotrope cells (Gracia-Navarro et al. 1992). At least two types of PACAP receptors, i.e. type I receptors (PACAP-specific receptors) and type II receptors (PACAP-VIP receptors) are expressed in the distal lobe of frog and toad (Alexandre et al. 1999, Hu et al. 2000). Concurrently, it has been shown that human (h) GHRH stimulates GH secretion from bullfrog pituitary cells, and that the hGHRH-induced GH release is inhibited by somatostatin in a dose-dependent manner (Jeandel et al. 1998). In addition, we have recently found that fGHRH-like peptide and fPACAP are equipotent in stimulating $\mathrm{GH}$ secretion from cultured frog adenohypophyseal cells (S Kikuyama, unpublished data). These observations suggest that, in amphibians, GHRH and PACAP (in addition to 
somatostatin) are involved in the neuroendocrine control of somatotrope cell activity (Table 1).

In fish, GHRH has been reported to exert a modest stimulatory effect in the trout Oncorhynchus mykiss (Luo et al. 1990, Blaise et al. 1995), the carp Cyprinus carpio (Vaughan et al. 1992) and the tilapia hybrid Oreochromis niloticus $\times$ Oreochromis aureus (Melamed et al. 1995) both in vitro and in vivo. In the salmon Oncorhynchus nerka, native GHRH produces only a weak stimulation of $\mathrm{GH}$ release from pituitary cells (Parker et al. 1997). In a primitive teleost, the European eel Anguilla anguilla, hGHRH is totally devoid of an effect on GH secretion (Montero et al. 1998). In contrast, both PACAP27 and PACAP38 provoke a robust stimulation of $\mathrm{GH}$ release from goldfish Carassius auratus (Wong et al. 1998) and eel pituitary cells (Montero et al. 1998). These observations strongly suggest that, in fish, PACAP rather than GHRH plays a physiological role in the control of $\mathrm{GH}$ secretion (Table 1). It should be noticed, however, that in the goldfish both type I PACAP receptor and a GHRH receptor are expressed in the pituitary (Chan et al. 1998, Wong et al. 1998), indicating that not only PACAP but also GHRH may exert some kind of hypophysiotropic activity. In addition, it has previously been shown that, in birds, amphibians and fish, several regulatory neuropeptides such as gonadotropin-releasing hormone (Marchant et al. 1989, Lin et al. 1993, Melamed et al. 1995), neuropeptide Y (Peng et al. 1990), thyrotropinreleasing hormone (Harvey et al. 1978, GraciaNavarro et al. 1991, Trudeau et al. 1992), cholecystokinin (Himick et al. 1993), bombesin (Himick \& Peter 1995) and corticotropin-releasing hormone (Rousseau et al. 1999) are involved in the control of somatotrope cell activity.

\section{CONCLUSIONS}

Since the identification of the sequence of secretin (Mutt et al. 1970), the characterization of multiple related peptides has provided insight into the molecular evolution of this large peptide superfamily. In the case of GHRH and PACAP, a series of exon and gene duplication events has led to the formation of a subfamily of neuropeptide precursors which exhibit the same overall organization. During vertebrate evolution, the primary structure of GHRH has markedly diverged while the sequence of PACAP has been strongly preserved. In submammalian vertebrates, GHRH and PACAP are arranged in tandem within the same precursor whereas, in mammals, the two peptides are generated from distinct precursors, suggesting that gene duplication may have occurred in a common ancestor during the transition period between birds and mammals (Fig. 4). Alternatively, submammalian vertebrates may possess two related GHRH/PACAP-encoding genes, one of which would remain to be characterized.

In all vertebrate species studied so far, the secretion of $\mathrm{GH}$ is under the dual control of inhibitory and stimulatory neuropeptides. While somatostatin acts as an inhibitor of $\mathrm{GH}$ release throughout the vertebrate phyllum, the respective roles of GHRH and PACAP as stimulatory factors of somatotrope cells have been radically inverted during evolution (Table 1). Recently, a novel hypothalamic neurohormone, termed ghrelin, has been characterized for its ability to stimulate $\mathrm{GH}$ secretion in mammals (Kojima et al. 1999). Identification of this novel neuropeptide in representative submammalian species and investigation of its possible GH-releasing activity will be necessary to understand the phylogenetic history of the control of $\mathrm{GH}$ secretion during vertebrate evolution.

\section{ACKNOWLEDGEMENTS}

This work was supported by grants from the Institut National de la Santé et de la Recherche Médicale (M M, L Y and H V), the Conseil Régional de Haute-Normandie (M M, L Y and $\mathrm{H} \mathrm{V})$, the Ministry of Education, Science and Culture of Japan (S K), the Centre National de la Recherche Scientifique (S D), the Conseil Supérieur de la Pêche (S D) and an INSERM-JSPS exchange program (S K and $\mathrm{H} \mathrm{V}$ ).

\section{REFERENCES}

Adams EF, Buchfelder M, Petersen B \& Fahlbusch R 1994 Effect of pituitary adenylate cyclase-activating polypeptide on human somatotrophic tumours in cell culture. Endocrine Fournal 2 75-79.

Alexandre D, Anouar Y, Jégou S, Fournier A \& Vaudry H 1999 A cloned frog vasoactive intestinal polypeptide/pituitary adenylate cyclase-activating polypeptide receptor exhibits pharmacological and tissue distribution characteristics of both VPAC1 and VPAC2 receptors in mammals. Endocrinology 140 1285-1293.

Alexandre D, Vaudry H, Jégou S \& Anouar Y 2000 Structure and distribution of the mRNAs encoding pituitary adenylate cyclase-activating polypeptide and growth hormone-releasing hormone-like peptide in the frog Rana ridibunda. Fournal of Comparative Neurology 421 234-246.

Arimura A 1998 Perspectives on pituitary adenylate cyclaseactivating polypeptide (PACAP) in the neuroendocrine, 
endocrine, and nervous systems. Fapanese Fournal of Physiology 48 301-331.

Arimura A, Somogyvari-Vigh A, Miyata A, Mizuno K, Coy DH \& Kitada C 1991 Tissue distribution of PACAP as determined by RIA: highly abundant in the rat brain and testes. Endocrinology 129 2787-2789.

Bell GI, Sanchez-Pescador R, Laybourn PJ \& Najarian RC 1983 Exon duplication and divergence in the human preproglucagon gene. Nature 304 368-371.

Bertherat J, Bluet-Pajot MT \& Epelbaum J 1995 Neuroendocrine regulation of growth hormone. European Fournal of Endocrinology 132 12-24.

Blaise O, Le Bail PY \& Weil C 1995 Lack of gonadotropinreleasing hormone action on in vivo and in vitro growth hormone release in rainbow trout (Oncorhynchus mykiss). Comparative Biochemistry and Physiology 110C 133-141.

Böhlen P, Esch F, Brazeau P, Ling N \& Guillemin R 1983 Isolation and characterization of the porcine hypothalamic growth hormone-releasing factor. Biochemical and Biophysical Research Communications 116 726-734.

Böhlen P, Wehrenberg WB, Esch F, Ling N, Brazeau P \& Guillemin R 1984 Rat hypothalamic growth hormonereleasing factor: isolation, sequence analysis and total synthesis. Biochemical and Biophysical Research Communications 125 1005-1012.

Brazeau P, Bohlen P, Esch F, Ling N, Wehrenberg WB \& Guillemin R 1984 Growth hormone-releasing factor from ovine and caprine hypothalamus: isolation, sequence analysis and total synthesis. Biochemical and Biophysical Research Communications 125 606-614.

Campbell RM \& Scanes CG 1992 Evolution of the growth hormone-releasing factor (GRF) family of peptides. Growth Regulation 2 175-191.

Carlquist M, Jörnvall H, Forssmann WG, Thulin L, Johansson C \& Mutt V 1985 Human secretin is not identical to the porcine/bovine hormone. IRCS Medical Science 13 217-218.

Chan KW, Yu KL, Rivier J \& Chow BK 1998 Identification and characterization of a receptor from goldfish specific for a teleost growth hormone-releasing hormone-like peptide. Neuroendocrinology 68 44-56.

Chartrel N, Tonon MC, Vaudry H \& Conlon JM 1991 Primary structure of frog pituitary adenylate cyclaseactivating polypeptide (PACAP) and effect of ovine PACAP on frog pituitary. Endocrinology 129 3367-3371.

Chiodera P, Volpi R, Capretti L, Caffarri G, Magotti MG \& Coiro V 1996 Effects of intravenously infused pituitary adenylate cyclase-activating polypeptide on adenohypophyseal hormone secretion in normal men. Neuroendocrinology 64 242-246.

Culler MD \& Paschall CS 1991 Pituitary adenylate cyclaseactivating polypeptide (PACAP) potentiates the gonadotropinreleasing activity of luteinizing hormone-releasing hormone. Endocrinology 129 2260-2262.

Esch F, Bohlen P, Ling N, Brazeau P \& Guillemin R 1983 Isolation and characterization of the bovine hypothalamic growth hormone-releasing factor. Biochemical and Biophysical Research Communications 117 772-779.

Frohman MA, Downs TR, Chomczynski P \& Frohman LA 1989 Cloning and characterization of mouse growth hormonereleasing hormone $(\mathrm{GRH})$ complementary DNA: increased GRH messenger RNA levels in the growth hormone-deficient lit/lit mouse. Molecular Endocrinology 3 1529-1536.

Ghatei MA, Takahashi K, Suzuki Y, Gardiner J, Jones PM \& Bloom SR 1993 Distribution, molecular characterization of pituitary adenylate cyclase-activating polypeptide and its precursor encoding messenger RNA in human and rat tissues. Fournal of Endocrinology 136 159-166.
Gonzalez BJ, Basille M, Vaudry D, Fournier A \& Vaudry H 1998 Pituitary adenylate cyclase-activating polypeptide. Annales d'Endocrinologie 59 364-405.

Goth MI, Lyons CE, Canny BJ \& Thorner MO 1992 Pituitary adenylate cyclase activating polypeptide, growth hormone (GH)-releasing peptide and GH-releasing hormone stimulate GH release through distinct pituitary receptors. Endocrinology 130 939-944.

Gracia-Navarro F, Castano JP, Malagon MM \& Torronteras R 1991 Subcellular responsiveness of amphibian hormone cells after TSH-releasing hormone stimulation. General and Comparative Endocrinology 84 94-103.

Gracia-Navarro F, Lamacz M, Tonon MC \& Vaudry H 1992 Pituitary adenylate cyclase-activating polypeptide stimulates calcium mobilization in amphibian pituitary cells. Endocrinology 131 1069-1074.

Gübler U, Monahan JJ, Lomedico PT, Bhatt RS, Collier KJ, Hoffman BJ, Böhlen P, Esch F, Ling N, Zeytin F, Brazeau P, Poonian MS \& Gage LP 1983 Cloning and sequence analysis of cDNA for the precursor of human growth hormone-releasing factor, somatocrinin. PNAS $\mathbf{8 0}$ 4311-4314.

Guillemin R, Brazeau P, Böhlen P, Esch F, Ling N \& Wehrenberg W 1982 Growth hormone-releasing factor from a human pancreatic tumor that caused acromegaly. Science $218585-587$.

Hart GR, Gowing H \& Burrin JM 1992 Effects of a novel hypothalamic peptide, pituitary adenylate cyclase-activating polypeptide, on pituitary hormone release in male rats. Fournal of Endocrinology 134 33-41.

Harvey S, Scanes CG, Chadwick A \& Bolton NJ 1978 The effect of thyrotropin-releasing hormone $(\mathrm{TRH})$ and somatostatin (GHRIH) on growth hormone and prolactin secretion in vitro and in vivo in the domestic fowl (Gallus domesticus). Neuroendocrinology 26 249-260.

Hashizume T, Soliman EB \& Kanematsu S 1994 Effects of pituitary adenylate cyclase-activating polypeptide (PACAP), prostaglandin $\mathrm{E}_{2}\left(\mathrm{PGE}_{2}\right)$ and growth hormone releasing factor $(\mathrm{GRF})$ on the release of growth hormone from cultured bovine anterior pituitary cells in vitro. Domestic Animal Endocrinology 11 331-337.

Himick BA \& Peter RE 1995 Bombesin-like immunoreactivity in the forebrain and pituitary and regulation of anterior pituitary hormone release by bombesin in goldfish. Neuroendocrinology 61 365-376.

Himick BA, Golosinski AA, Jonsson AC \& Peter RE 1993 $\mathrm{CCK} /$ gastrin-like immunoreactivity in the goldfish pituitary: regulation of pituitary hormone secretion by CCK-like peptides in vitro. General and Comparative Endocrinology 92 88-103.

Hosoya M, Kimura C, Ogi K, Ohkubo S, Miyamoto Y, Kugoh H, Shimizu M, Onda H, Oshimura M, Arimura A \& Fujino M 1992 Structure of the human pituitary adenylate cyclaseactivating polypeptide (PACAP) gene. Biochimica et Biophysica Acta 1129 199-206.

Hoyle CHV 1998 Neuropeptide families: evolutionary perspectives. Regulatory Peptides 73 1-33.

Hu Z, Lelievre V, Chao A, Zhou X \& Waschek JA 2000 Characterization and messenger ribonucleic acid distribution of a cloned pituitary adenylate cyclase-activating polypeptide type I receptor in the frog Xenopus laevis brain. Endocrinology $141657-665$.

Itoh N, Obata K, Yanaihara N \& Okamoto H 1983 Human preprovasoactive intestinal polypeptide contains a novel PHI-27-like peptide, PHM-27. Nature 304 547-549.

Jarry H, Leonhardt S, Schmidt WE, Creutzfeld W \& Wuttke W 1992 Contrasting effects of pituitary adenylate cyclaseactivating polypeptide (PACAP) on in vivo and in vitro 
prolactin and growth hormone release in male rats. Life Sciences $\mathbf{5 1} 823-830$.

Jeandel L, Okuno A, Kobayashi T, Kikuyama S, Tostivint H, Lihrmann I, Chartrel N, Conlon JM, Fournier A, Tonon MC \& Vaudry H 1998 Effects of the two somatostatin variants somatostatin-14 and [Pro2, Met13] somatostatin-14 on receptor binding, adenylyl cyclase activity and growth hormone release from the frog pituitary. Fournal of Neuroendocrinology 1998 187-192.

Kieffer TJ \& Habener JF 1999 The glucagon-like peptides. Endocrine Reviews 20 876-913.

Kimura C, Ohkubo S, Ogi K, Hosoya M, Itoh Y, Onda H, Miyata A, Jiang L, Dahl RR \& Stibbs HH 1990 A novel peptide which stimulates adenylate cyclase: molecular cloning and characterization of the ovine and human cDNAs. Biochemical and Biophysical Research Communications 166 81-89.

Kojima M, Hosoda H, Date Y, Nakazato M, Matsuo H \& Kangawa K 1999 Ghrelin is a growth-hormone-releasing acylated peptide from stomach. Nature 402 656-660.

Koves K, Arimura A, Gorcs TG \& Somogyvari-Vigh 1991 Comparative distribution of immunoreactive pituitary adenylate cyclase activating polypeptide and vasoactive intestinal polypeptide in the rat forebrain. Neuroendocrinology 54 159-169.

Koves K, Gorcs TJ, Kausz M \& Arimura A 1994 Present status of knowledge about the distribution and colocalization of PACAP in the forebrain. Acta Biologica Hungarica 45 297-321.

Legradi G, Shioda S \& Arimura A 1994 Pituitary adenylate cyclase-activating polypeptide-like immunoreactivity in autonomic regulatory areas of the rat medulla oblongata. Neuroscience Letters 176 193-196.

Leonhardt S, Jarry H, Kreipe A, Werstler K \& Wuttke W 1992 Pituitary adenylate cyclase-activating polypeptide (PACAP) stimulates pituitary hormone release in male rats. Neuroendocrinology Letters 14 319-328.

Leung MY, Tse LY, Yu KL, Chow BKC \& Wong AOL 1999 Molecular cloning and tissue distribution of PACAP in the goldfish. In Recent Progress in Molecular and Comparative Endocrinology, pp 383-388. Eds HB Kwon, JMP Joss \& S Ishii. Kwangju: Hormone Research Center, Chonnam National University.

Lin XW, Lin HR \& Peter RE 1993 Growth hormone and gonadotropin secretion in the common carp (Cyprinus carpio L.): in vitro interactions of gonadotropin-releasing hormone, somatostatin, and the dopamine agonist apomorphine. General and Comparative Endocrinology 89 62-71.

Ling N, Esch F, Böhlen P, Brazeau P, Wehrenberg WB \& Guillemin R 1984 Isolation, primary structure, and synthesis of human hypothalamic somatocrinin: growth hormone-releasing factor. PNAS 81 4302-4306.

Luo D, McKeown BA, Rivier J \& Vale W 1990 In vitro responses of rainbow trout (Oncorhynchus mykiss) somatotrophs to carp growth hormone-releasing factor (GRF) and somatostatin. General and Comparative Endocrinology 80 288-298.

McRory JE \& Sherwood NM 1997 Two protochordate genes encode pituitary adenylate cyclase-activating polypeptide and related family members. Endocrinology $\mathbf{1 3 8}$ 2380-2390.

McRory JE, Parker DB, Ngamvongchon S \& Sherwood NM 1995 Sequence and expression of cDNA for pituitary adenylate cyclase-activating polypeptide (PACAP) and growth hormone-releasing hormone (GHRH)-like peptide in catfish. Molecular and Cellular Endocrinology 108 169-177.

McRory JE, Parker RL \& Sherwood NM 1997 Expression and alternative processing of a chicken gene encoding both growth hormone-releasing hormone and pituitary adenylate cyclase-activating polypeptide. DNA and Cell Biology 16 95-102.

Marchant TA, Chang JP, Nahorniak CS \& Peter RE 1989 Evidence that gonadotropin-releasing hormone also functions as a growth hormone-releasing factor in the goldfish. Endocrinology 124 2509-2518.

Marivoet S, Moons L \& Vandesande F 1988 Localization of growth hormone-releasing factor-like immunoreactivity in the hypothalamo-hypophyseal system of the frog (Rana temporaria) and the sea bass (Dicentrarchus labrax). General and Comparative Endocrinology 72 72-79.

Martinez-Fuentes AJ, Gonzalez de Aguilar JL, Lacuisse S, Kikuyama S, Vaudry H \& Gracia-Navarro F 1994 Effect of frog pituitary adenylate cyclase-activating polypeptide (PACAP) on amphibian pituitary cells. In Vasoactive Intestinal Peptide, Pituitary Adenylate Cyclase-Activating Polypeptide and Related Regulatory Peptides: from Molecular Biology to Clinical Applications, pp 376-380. Ed G Rosselin. Singapore: World Scientific.

Matsuda K, Takei Y, Katoh JI, Shioda S, Arimura A \& Uchiyama M $1997 a$ Isolation and structural characterization of pituitary adenylate cyclase-activating polypeptide (PACAP)-like peptide from the brain of the teleost, stargazer Uranoscopus japonicus. Peptides 18 725-727.

Matsuda K, Shioda S, Arimura A \& Uchiyama M 1997b The study of pituitary adenylate cyclase-activating polypeptide (PACAP)-like immunoreactivity in the brain of teleost, stargazer Uranoscopus japonicus. Zoological Science 14 645-650.

Matsuda K, Yoshida T, Nagano Y, Kashimoto K, Yatohgo T, Shimomura H, Shioda S, Arimura A \& Uchiyama M 1998 Purification and primary structure of pituitary adenylate cyclase-activating polypeptide (PACAP) from the brain of an elasmobranch, stingray Dasyatis akajei. Peptides 19 1489-1495.

Mayo KE, Vale W, Rivier J, Rosenfeld MG \& Evans RM 1983 Expression-cloning and sequence of a cDNA encoding human growth hormone-releasing factor. Nature 306 86-88.

Mayo KE, Cerelli GM, Lebo RV, Bruce BD, Rosenfeld MG \& Evans RM 1985a Gene encoding human growth hormonereleasing factor precursor. Structure, sequence, and chromosomal assignment. PNAS 82 63-67.

Mayo KE, Cerelli G, Rosenfeld MG \& Evans RM $1985 b$ Characterization of cDNA and genomic clones encoding the precursor to rat hypothalamic growth hormone-releasing factor. Nature 314 464-467.

Mayo KE, Godfrey PA, Suhr ST, Kulik DJ \& Rahal JO 1995 Growth hormone-releasing hormone: synthesis and signaling. Recent Progress in Hormone Research 50 35-73.

Melamed P, Eliahu N, Levavi-Sivan B, Ofir M, Farchi-Pisanty O, Rentier-Delerue F, Smal J, Yaron Z \& Naor Z 1995 Hypothalamic and thyroidal regulation of growth hormone in tilapia. General and Comparative Endocrinology 97 13-30.

Miyata A, Arimura A, Dahl DH, Minamino N, Uehara A, Jiang L, Culler MD \& Coy DH 1989 Isolation of a novel 38 residue hypothalamic peptide which stimulates adenylate cyclase in pituitary cells. Biochemical and Biophysical Research Communications 164 567-574.

Miyata A, Dahl DH, Jiang L, Kitada C, Kubo K, Fujino M, Minamino N \& Arimura A 1990 Isolation of a neuropeptide corresponding to the $\mathrm{N}$-terminal 27 residues of the pituitary adenylate cyclase activating polypeptide with 38 residues (PACAP38). Biochemical and Biophysical Research Communications 170 643-648.

Montero M, Yon L, Rousseau K, Arimura A, Fournier A, Dufour S \& Vaudry H 1998 Distribution, characterization, and growth hormone-releasing activity of pituitary adenylate 
cyclase-activating polypeptide in the European eel Anguilla anguilla. Endocrinology 139 4300-4310.

Moody AJ, Thim L \& Valverde I 1984 The isolation and sequencing of human gastric inhibitory peptide (GIP). FEBS Letters 172 142-148.

Mutt V, Jorpes JE \& Magnusson S 1970 Structure of porcine secretin. The amino acid sequence. European Fournal of Biochemistry 15 513-519.

Nagy GM, Vigh S \& Arimura A 1993 PACAP induces prolactin and growth hormone release in lactating rats separated from their pups. Endocrine fournal 1 169-173.

Nielsen HS, Hannibal J \& Fahrenkrug J 1998 Expression of pituitary adenylate cyclase activating polypeptide (PACAP) in the postnatal and adult rat cerebellar cortex. Neuroreport 9 2639-2642.

Ogi K, Kimura C, Onda H, Arimura A \& Fujino M 1990 Molecular cloning and characterization of cDNA for the precursor of rat pituitary adenylate cyclase-activating polypeptide (PACAP). Biochemical and Biophysical Research Communications 173 1271-1279.

Ohkubo S, Kimura C, Ogi K, Okazaki K, Hosoya M, Onda H, Miyata A, Arimura A \& Fujino M 1992 Primary structure and characterization of the precursor to human pituitary adenylate cyclase-activating polypeptide. DNA and Cell Biology 11 21-30.

Okazaki K, Itoh Y, Ogi K, Ohkubo S \& Onda H 1995 Characterization of murine PACAP mRNA. Peptides 16 1295-1299.

Olivereau M, Olivereau J \& Vandesande F 1990 Localization of growth hormone-releasing factor-like immunoreactivity in the hypothalamo-hypophysial system of some teleost species. Cell and Tissue Research 259 73-80.

Ono M, Miki N, Demura H, Tadokoro K, Nagafuchi S \& Yamada M 1994 Molecular cloning of cDNA encoding the precursor for hamster hypothalamic growth hormonereleasing factor. DNA Sequence 5 93-102.

Parker DB, Coe IR, Dixon GH \& Sherwood NM 1993 Two salmon neuropeptides encoded by one brain cDNA are structurally related to members of the glucagon superfamily. European Fournal of Biochemistry 215 439-448.

Parker DB, Power ME, Swanson P, Rivier J \& Sherwood NM 1997 Exon skipping in the gene encoding pituitary adenylate cyclase-activating polypeptide in salmon alters the expression of two hormones that stimulate growth hormone release. Endocrinology 138 413-423.

Peeters K, Berghman LR \& Vandesande F 1998a Comparative distribution of pituitary adenylate cyclase-activating polypeptide and vasoactive intestinal polypeptide immunoreactivity in the chicken forebrain. Annals of the New York Academy of Sciences 839 417-419.

Peeters K, Langouche L, Vandesande F, Darras VM \& Berghman LR $1998 b$ Effects of pituitary adenylate cyclaseactivating polypeptide (PACAP) on cAMP formation and growth hormone release from chicken anterior pituitary cells. Annals of the New York Academy of Sciences $\mathbf{8 6 5}$ 471-475.

Peng C, Huang YP \& Peter RE 1990 Neuropeptide Y stimulates growth hormone and gonadotropin release from the goldfish pituitary in vitro. Neuroendocrinology $\mathbf{5 2}$ 28-34.

Pohl M \& Wank SA 1998 Molecular cloning of the helodermin and exendin-4 cDNAs in the lizard. Fournal of Biological Chemistry 273 9778-9784.

Rivier J, Spiess J, Thorner M \& Vale W 1982 Characterization of growth hormone-releasing factor from a human pancreatic islet tumour. Nature 300 276-278.

Rousseau K, Le Belle N, Marchelidon J \& Dufour S 1999 Evidence that corticotropin-releasing hormone $(\mathrm{CRH})$ acts as a growth hormone-releasing factor in a primitive teleost, the European eel Anguilla anguilla. Fournal of Neuroendocrinology $11385-392$.

Satoh M, Uchiyama M, Nakajo S, Shioda S, Arimura A \& Matsuda K 1999 Expression of pituitary adenylate cyclase activating polypeptide (PACAP) mRNA in the brain of a teleost, stargazer. Zoological Science 16 (Suppl) 18.

Sawangjaroen K \& Curlewis JD 1994 Effects of pituitary adenylate cyclase-activating polypeptide (PACAP) and vasoactive intestinal polypeptide (VIP) on prolactin, luteinizing hormone and growth hormone secretion in the ewe. Fournal of Neuroendocrinology 5 549-555.

Sawangjaroen K, Anderson ST \& Curlewis JD 1997 Effects of pituitary adenylate cyclase-activating polypeptide (PACAP) and vasoactive intestinal polypeptide (VIP) on hormone secretion from sheep pituitary cells in vitro. Fournal of Neuroendocrinology 9 279-286.

Spiess J, Rivier J \& Vale W 1983 Characterization of rat hypothalamic growth hormone-releasing factor. Nature 303 532-535.

Suhr ST, Rahal JO \& Mayo KE 1989 Mouse growth hormone-releasing hormone: precursor structure and expression in brain and placenta. Molecular Endocrinology 3 1693-1700.

Trudeau VL, Somoza GM, Nahorniak CS \& Peter RE 1992 Interactions of estradiol with gonadotropin-releasing hormone and thyrotropin-releasing hormone in the control of growth hormone secretion in the goldfish. Neuroendocrinology $56483-490$.

Vaudry D, Gonzalez BJ, Basille M, Yon L, Fournier A \& Vaudry H 2000 Pituitary adenylate cyclase-activating polypeptide and its receptors: from structure to functions. Pharmacological Reviews 52 269-324.

Vaughan JM, Rivier JE, Spiess J, Peng C, Chang JP, Peter P \& Vale W 1992 Isolation and characterization of hypothalamic growth hormone-releasing hormone from common carp Cyprinus carpio. Neuroendocrinology 56 539-549.

Velkeniers B, Zheng L, Kazemzadeh M, Robberecht P, Vanhaelst L \& Hooghe-Peters EL 1994 Effect of pituitary adenylate cyclase-activating polypeptide 38 on growth hormone and prolactin expression. Fournal of Endocrinology $1431-11$.

Wei L, Chan WWS, Butler B \& Cheng K 1993 Pituitary adenylate cyclase-activating polypeptide-induced desensitization on growth hormone release from rat primary pituitary cells. Biochemical and Biophysical Research Communications 197 1396-1401.

Wong AOL, Leung MY, Shea WLC, Tse LY, Chang JP \& Chow BKC 1998 Hypophysiotropic action of pituitary adenylate cyclase-activating polypeptide (PACAP) in the goldfish: immunohistochemical demonstration of PACAP in the pituitary, PACAP stimulation of growth hormone release from pituitary cells, and molecular cloning of pituitary type I PACAP receptor. Endocrinology 139 3465-3479.

Yamamoto K, Hashimoto H, Hagihara N, Nishino A, Fujita T, Matsuda T \& Baba A 1998 Cloning and characterization of the mouse pituitary adenylate cyclase-activating polypeptide (PACAP) gene. Gene 211 63-69.

Yon L, Feuilloley M, Chartrel N, Arimura A, Conlon JM, Fournier A \& Vaudry H 1992 Immunohistochemical distribution and biological activity of pituitary adenylate cyclase-activating polypeptide (PACAP) in the central nervous system of the frog Rana ridibunda. Fournal of Comparative Neurology 324 485-499.

Yon L, Jeandel L, Chartrel N, Feuilloley M, Conlon JM, Arimura A, Fournier A \& Vaudry H 1993 Neuroanatomical and physiological evidence for the involvement of pituitary 
adenylate cyclase-activating polypeptide in the regulation of the distal lobe of the frog pituitary. Fournal of

Neuroendocrinology 5 289-296.

Yoshida T, Itoh Y, Uchiyama M, Shioda S, Arimura A,

Kashimoto K \& Matsuda K 1999 Distribution of pituitary adenylate cyclase activating polypeptide (PACAP)-like immunoreactivity in the brain of an elasmobranch, stingray. Zoological Science 16 (Suppl) 18.

RECEIVED 2 March 2000 